\title{
Gambaran Pengetahuan dan Sikap Ibu Hamil Tentang Antenatal Care di Puskemas Aur Duri Kota Jambi Tahun 2018
}

\author{
Gustina \\ Midwifery Program (Dipl) STIKBA Jambi \\ Email : tinamagisterbidan@gmail.com
}

\begin{abstract}
In 2015 mortality rate in indonesia is 305 per 100.000 live births. Compared to other countries the maternal mortality rate in indonesia is still relatively high. Maternal death can be prevented by conducting antenatal care. This study aimed to determine the description of knowledge and the attitude of the pregnant mother about antenatal care at the public health center Aur Duri Jambi city year 2018. This is descriptive research. This study was conducted in Jambi on August $20^{\text {th }}-25^{\text {th }} 2018$ with populations were pregnant mothers at the public health center Aur Duri Jambi city year 2018 as many as 393 pregnant mothers. Samples used accidental sampling technique as many as 40 pregnant mothers. The collecting of data used interview. Data analyzed as univariate. The findings were obtained the most of pregnant mothers have good knowledge were 27 (67.5\%). Most of pregnant mothers have positive attitude were 25 (62.5\%) and most of pregnant mothers did antenatal care well that is 36 (90\%) pregnant mothers. This study can be concluded the mothers have had good knowledge, a positive attitude and do antenatal care well. For the health personal further enhance counseling about antenatal care that is not only done fpr pregnant mother but also for the community.
\end{abstract}

Keywords:

Knowledge, Attitude, Antenatal Care

\section{PENDAHULUAN}

Menurut laporan World Health Organization (WHO) tahun 2014 Angka Kematian Ibu (AKI) di dunia yaitu 289.000 jiwa.

Survey Demografi Kesehatan Indonesia (SDKI) tahun 2012 menunjukkan Angka Kematian Ibu (AKI) sebesar 359 per 100.000 kelahiran hidup, meningkat dibandingkan hasil SDKI tahun 2007 sebesar 228 per 100.000 kelahiran hidup. Pada tahun 2015 AKI kembali menunjukkan penurunan menjadi 305 kematian ibu per 100.000 kelahiran hidup berdasarkan hasil Survei Penduduk Antar Sensus (SUPAS) tahun 2015. Pada tahun 2015 angka kematian ibu mengalami penurunan di tahun 2012 sebesar 359 per 100.000 kelahiran hidup menjadi 305 kematian ibu per 100.000 kelahiran hidup di tahun 2015. Namun, dibandingkan dengan negara-negara lainnya AKI di Indonesia masih tinggi (Kemenkes RI, 2016).

Angka kematian ibu di Provinsi Jambi pada tahun 2011 yaitu 112 per 100.000 kelahiran hidup, tahun 2012 yaitu 110 per 100.000 kelahiran hidup dan mengalami penurunan di tahun 2013 yaitu 82 per100.000 kelahiran hidup, dan tahun 2014 yaitu 75 per 100.000 kelahiran hidup kemudian mengalami lagi peningkatan di tahun 2015 yaitu 81 per 100.000 kelahiran hidup dan tahun 2016 meningkat kembali menjadi 87 per 100.000 kelahiran hidup. Kematian ibu di Kota Jambi berjumlah 3 orang (Dinkes Provinsi Jambi, 2016).

Kematian ibu dapat dicegah dengan melakukan asuhan antenatal, karena asuhan antenatal yang baik sangat penting untuk hasil kehamilan yang baik karena sebagian besar dari kematian ibu bisa dicegah melalui asuhan antenatal, intranatal, dan postnatal yang bermutu tinggi (Hanni, 2010).

Sebagai seorang bidan dalam melaksanakan prakteknya harus sesuai dengan standar pelayanan kebidanan yang berlaku. Standar mencerminkan norma, pengetahuan dan tingkat kinerja yang telah disepakati oleh profesi. Penerapan standar pelayanan akan sekaligus melindungi masyarakat karena penilaian terhadap proses dan hasil pelayanan dapat dilakukan atas dasar yang jelas. Kelalaian dalam praktek kebidanan dapat terjadi bila pelayanan yang diberikan tidak memenuhi standar (Walyani, 2015).

Standar dalam memberikan asuhan kehamilan dengan standar $10 \mathrm{~T}$ dalam penerapannya terdiri atas timbang berat badan dan ukur tinggi badan, ukur tekanan darah, nilai status gizi (ukur lingkar lengan atas), ukur tinggi fundus uteri, tentukan presentasi janin dan denyut jantung janin (DJJ), skrining status imunisasi tetanus dan berikan imunisasi Tetanus Toksoid (TT) bila diperlukan, pemberian tablet zat besi minimal 90 tablet selama kehamilan, test laboratorium (rutin dan khusus), tatalaksana kasus, temu wicara (konseling), termasuk Perencanaan Persalinan dan Pencegahan Komplikasi (P4K) serta KB pasca persalinan (Kemenkes RI, 2010).

Keuntungan melakukan ANC yaitu dapat mengetahui berbagai resiko dan komplikasi hamil sehingga ibu hamil dapat diarahkan untuk melakukan rujukan kerumah sakit (Manuaba, 2013) Akibat yang dapat ditimbulkan jika ibu hamil tidak melakukan pemerikasaan kehamilan yaitu komplikasi obstetri yang mungkin terjadi 
selama kehamilan tidak dapat di deteksi sedini mungkin serta di tangani secara memadai. Komplikasi obstetri itu antara lain komplikasi obstetri langsung (perdarahan, preeklamsi/eklamsi, kelainan letak, anak besar, kehamilan kembar, ketuban pecah dini), komplikasi obstetri tidak langsung (sakit jantung, hepatitis, tuberkulosa, anemia, diabetes melitus) dan komplikasi yang berhubungan dengan obstetric (cedera akibat kecelakaan kendaraan, keracunan, kebakaran) (Novita, 2013).

Berdasarkan data yang didapat dari Dinas Kesehatan Kota Jambi jumlah cakupan ibu hamil K1 dan K4 di 20 Puskesmas Kota Jambi Tahun 2017.

Jumlah cakupan K1 di Kota Jambi sebanyak $14.166(97,07 \%)$ dan jumlah cakupan K4 sebanyak $13.626 \quad(93,37 \%)$ dari jumlah sasaran ibu hamil di Kota Jambi sebanyak 14.593. Jumlah cakupan K1 dan K4 terendah terdapat di Puskesmas Aur Duri dengan cakupan K1 415 (84,01\%) dan jumlah cakupan K4 401 (81,17\%).

\section{METODE PENELITIAN}

Penelitian ini adalah deskriptif. Penelitian dilakukan di puskesmas Aur Duri Kota Jambi tahun 2018 yaitu dengan populasi 393 ibu hamil dan sampel diambil menggunakan teknik accidental sampling berjumlah 40 ibu hamil. Pengumpulan data melalui wawancara menggunakan kuisioner. Hasil pengumpulan data dianalisis secara univariat. Penelitian dilakukan Puskesmas Aur Duri Kota Jambi dari tanggal $20-25$ Agustus 2018.

\section{HASIL DAN PEMBAHASAN Karakteristik ibu hamil}

a. Umur

Karakteristik ibu hamil berdasarkan umur dapat dilihat dari tabel berikut:

Tabel 1 Distribusi lbu hamil Berdasarkan Umur Ibu Hamil di Puskesmas Aur Duri Kota Jambi Tahun 2018

\begin{tabular}{cccc}
\hline NO & Umur Ibu & Jumlah & Persentase (\%) \\
\hline 1. & $<20$ tahun & 1 & 2,5 \\
2. & $20-35$ tahun & 31 & 77,5 \\
3. & $>35$ tahun & 8 & 20,0 \\
& Jumlah & 40 & 100 \\
\hline
\end{tabular}

Berdasarkan tabel 1 diperoleh gambaran bahwa sebagian besar umur ibu hamil berusia $20-35$ tahun sebanyak 31 (77,5\%) ibu hamil.

b. Tingkat pendidikan

Karakteristik ibu hamil berdasarkan tingkat pendidikan dapat dilihat pada tabel berikut:
Tabel 2 Distribusi lbu hamil Berdasarkan Tingkat Pendidikan lbu Hamil di Puskesmas Aur Duri Kota Jambi Tahun 2018.

\begin{tabular}{clcc}
\hline No & Tingkat Pendidikan & Jumlah & Persentase (\%) \\
\hline 1. & SD/sederajat & 2 & 5,0 \\
2. & SMP/sederajat & 5 & 12,5 \\
3. & SMA/sederajat & 24 & 60,0 \\
4. & Perguruan Tinggi & 9 & 22,5 \\
& Jumlah & 40 & 100 \\
\hline
\end{tabular}

Berdasarkan tabel 2 diperoleh gambaran bahwa tingkat pendidikan ibu hamil sebagian besar pada tingkat pendidikan SMA/sederajat yaitu sebanyak 24 (60\%) ibu hamil.

c. Pekerjaan

Karakteristik ibu hamil berdasarkan pekerjaan dapat dilihat pada tabel berikut:

Tabel 3 Distribusi lbu hamil Berdasarkan Pekerjaan Ibu Hamil di Puskesmas Aur Duri Kota Jambi Tahun 2018

\begin{tabular}{clcc}
\hline No & $\begin{array}{c}\text { Tingkat } \\
\text { Pekerjaan }\end{array}$ & Jumlah & Persentase (\%) \\
\hline 1. & IRT & 30 & 75,0 \\
2. & Swasta & 5 & 12,5 \\
3. & PNS & 3 & 7,5 \\
4. & Honorer & 1 & 2,5 \\
5. & Lain-lain & 1 & 2,5 \\
& Jumlah & 40 & 100 \\
\hline
\end{tabular}

Berdasarkan tabel 3 diperoleh gambaran bahwa pekerjaan ibu hamil sebagian besar adalah ibu rumah tangga yaitu sebanyak 30 (75\%) ibu hamil.

d. Usia Kehamilan

Karakteristik ibu hamil berdasarkan usia kehamilan dapat dilihat pada tabel berikut:

Tabel 4 Distribusi Ibu hamil Berdasarkan Usia Kehamilan Ibu Hamil di Puskesmas Aur Duri Kota Jambi Tahun 2018

\begin{tabular}{clcc}
\hline No & Usia Kehamilan & Jumlah & Persentase (\%) \\
\hline 1. & $0-12$ minggu & 8 & 20,0 \\
2. & $13-28$ minggu & 13 & 32,5 \\
3. & 29-42 minggu & 19 & 47,5 \\
& Jumlah & 40 & 100 \\
\hline
\end{tabular}

Berdasarkan tabel 4 diperoleh gambaran bahwa sebagian besar usia kehamilan ibu hamil adalah 29-42 minggu yaitu sebanyak $19(47,5 \%)$ ibu hamil .

e. Usia Kehamilan Berdasarkan Kunjungan ANC

Karakteristik usia kehamilan ibu hamil berdasarkan kunjungan ANC dapat dilihat pada tabel berikut:

Tabel 5 Distribusi lbu hamil Berdasarkan Usia Kehamilan Ibu Hamil di Puskesmas Aur Duri Kota Jambi

\begin{tabular}{|c|c|c|c|c|c|}
\hline \multirow{3}{*}{ No } & \multirow{3}{*}{$\begin{array}{c}\text { Usia } \\
\text { Kehamilan }\end{array}$} & \multirow{2}{*}{\multicolumn{2}{|c|}{ Tidak Teratur }} & \multirow{2}{*}{\multicolumn{2}{|c|}{ Teratur }} \\
\hline & & & & & \\
\hline & & Jumlah & $\%$ & Jumlah & $\%$ \\
\hline 1. & 0-12 mgg & 1 & 2,5 & 7 & 17,5 \\
\hline 2. & $13-28 \mathrm{mgg}$ & 2 & 5,0 & 11 & 27,5 \\
\hline \multirow{2}{*}{3.} & $29-42 \mathrm{mgg}$ & 1 & 2,5 & 18 & 45,0 \\
\hline & Jumlah & 4 & 10,0 & 36 & 90,0 \\
\hline
\end{tabular}

Berdasarkan tabel 5 diperoleh gambaran bahwa sebagian besar kunjungan ibu hamil 
yang tidak teratur pada usia kehamilan 13-28 minggu yaitu sebanyak $2(5 \%)$ ibu hamil dan sebagian besar kunjungan ibu hamil yang teratur pada usia kehamilan 29-42 minggu 18 $(45 \%)$ ibu hamil.

\section{Gambaran Pengetahuan Ibu Hamil Tentang Antenatal Care di Puskesmas Aur Duri Kota Jambi Tahun 2018}

Diagram 1 Tingkat Pengetahuan Ibu Hamil Tentang Antenatal Care di Puskesmas Aur Duri Kota Jambi Tahun 2018

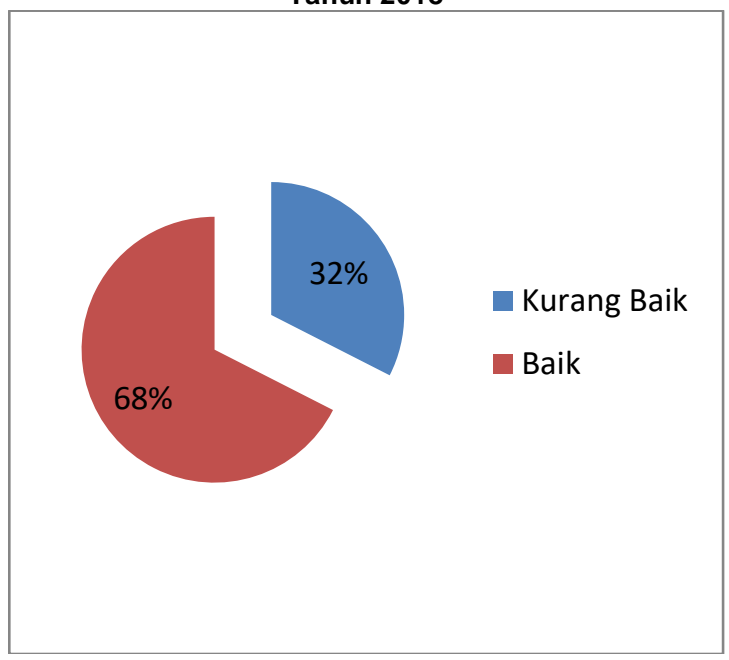

Berdasarkan diagram 1 dapat diketahui bahwa ibu hamil yang memiliki pengetahuan baik yaitu $27(67,5 \%)$ ibu hamil dan yang memiliki pengetahuan kurang baik sebanyak 13 $(32,5 \%)$ ibu hamil.

\section{Gambaran Sikap lbu Hamil Tentang Antenatal Care di Puskesmas Aur Duri Kota Jambi Tahun 2018}

Sikap dikategorikan menjadi dua yaitu positif jika skor jawaban $\geq 48,97$ nilai mean dan negatif jika skor jawaban $<48,97$ nilai mean. Berdasarkan kategori tersebut di dapatkan hasil bahwa sikap ibu hamil tentang antenatal care dapat dilihat pada diagram dibawah ini:

Diagram 2 Tingkat Sikap Ibu Hamil Tentang Antenatal Care di Puskesmas Aur Duri Kota Jambi Tahun 2018

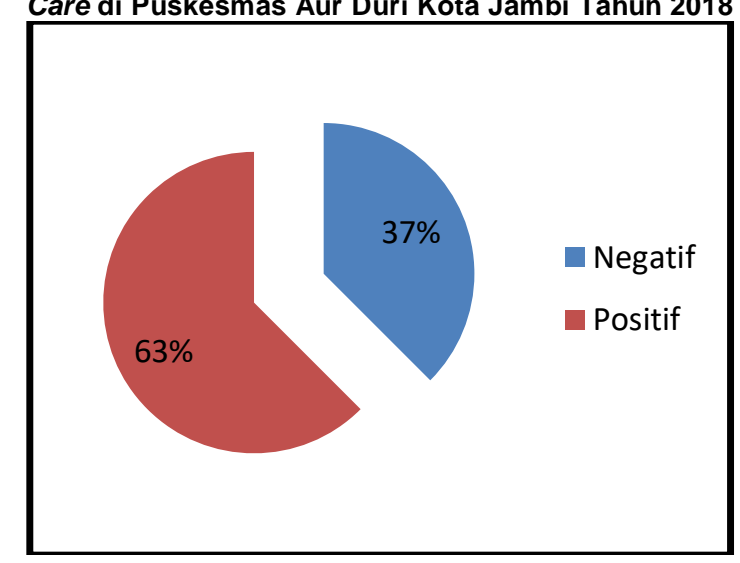

Berdasarkan diagram 2, dapat diketahui bahwa yang memiliki sikap positif yaitu 25 $(62,5 \%)$ ibu hamil dan yang memiliki sikap negatif sebanyak $15(37,5 \%)$ ibu hamil.

\section{Gambaran Antenatal Care Pada lbu Hamil di} Puskesmas Aur Duri Kota Jambi Tahun 2018

Dalam penelitian ini untuk mengetahui gambaran antenatal care di Puskesmas Aur Duri Kota Jambi tahun 2018 dapat dilihat pada diagram dibawah ini:

Diagram 3 Gambaran Antenatal Care Pada lbu Hamil di Puskesmas Aur Duri Kota Jambi Tahun 2018

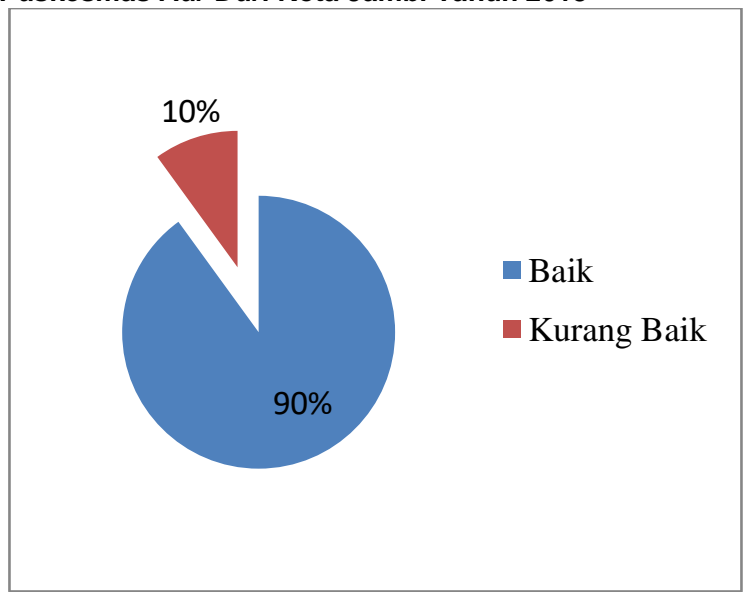

Berdasarkan diagram 3 dapat diketahui bahwa ibu hamil yang melakukan antenatal care dengan baik yaitu $36(90 \%)$ ibu hamil dan yang melakukan antenatal care kurang baik sebanyak $4(10 \%)$ ibu hamil.

Tabel 6. Distribusi lbu hamil Berdasarkan Pemeriksaan Kehamilan Sesuai Usia Kehamilan Dengan Waktu Yang Dianjurkan di Puskesmas Aur Duri Kota Jambi Tahun

\begin{tabular}{cccccc}
\multicolumn{9}{c}{$\mathbf{2 0 1 8}$} \\
\hline No & Usia & \multicolumn{2}{c}{ Tidak Teratur } & \multicolumn{2}{c}{ Teratur } \\
& Kehamilan & Jumlah & $\%$ & Jumlah & $\%$ \\
\hline 1. & $0-12 \mathrm{mgg}$ & 1 & 2,5 & 7 & 17,5 \\
2. & $13-28 \mathrm{mgg}$ & 2 & 5,0 & 11 & 27,5 \\
3. & $29-42 \mathrm{mgg}$ & 1 & 2,5 & 18 & 45,0 \\
& Jumlah & 4 & 10,0 & 36 & 90,0 \\
\hline
\end{tabular}

Berdasarkan tabel 6 dapat diketahui bahwa ibu hamil yang melakukan kunjungan sesuai usia kehamilan dan antenatal care baik yang baik yaitu $36(90 \%)$ ibu hamil dan yang melakukan kunjungan tidak sesuai dengan usia kehamilan dan antenatal care kurang baik sebanyak 4 (10\%) ibu hamil.

\section{Pembahasan}

Gambaran Pengetahuan Ibu Hamil Tentang Antenatal Care di Puskesmas Aur Duri Kota Jambi Tahun 2018

Berdasarkan hasil penelitian diperoleh dari 40 responden ibu hamil gambaran bahwa ibu hamil yang memiliki pengetahuan baik yaitu $27(67,5 \%)$ ibu hamil dan yang memiliki 
pengetahuan kurang baik sebanyak $13(32,5 \%)$ ibu hamil.

Hasil penelitian ini sejalan dengan hasil penelitian yang dilakukan Purwantini tahun 2012 mengenai gambaran tingkat pengetahuan ibu hamil dalam pemeriksaan antenatal care di Wilayah Kerja Puskesmas Jambon Kabupaten Ponorogo didapat hasil bahwa 53 responden memiliki pengetahuan yang baik dan 27 responden memiliki pengetahuan yang kurang baik. Namun hasil penelitian ini tidak sejalan dengan hasil penelitian Gusputrya (2016) mengenai gambaran pengetahuan dan sikap ibu hamil trimester III tentang antenatal care di Puskesmas Talang Bakung Kota Jambi Tahun 2016 didapat bahwa sebagian besar pengetahuan responden dalam kategori baik yaitu $12,1 \%$.

Hasil penelitian didapat responden yang memiliki pengetahuan baik dapat dipengaruhi oleh pendidikan yang dimiliki responden karena terdapat $60 \%$ responden memiliki tingkat pendidikan SMA/sederajat sehingga dengan tingginya pendidikan yang dimiliki akan mudah untuk mengaplikasikan pengetahuan tentang antenatal care. Selain itu sebagian besar responden berusia 20-35 tahun sebanyak 77,5\% responden dengan usia responden yang produktif sehingga responden lebih mendapatkan informasi mengenai antenatal care dan mengaplikasikan pengetahuan yang dimiliki. Selain itu responden yang masih memiliki pengetahuan kurang baik dapat dipengaruhi oleh pendidikan responden karena masih terdapat responden yang berpendidikan SMP/sederajat sebanyak $12,5 \%$ ibu hamil dan $\mathrm{SD} /$ sederajat sebanyak $5,0 \%$ ibu hamil sehingga dengan pendidikan yang rendah sulit mengaplikasikan pengetahuan yang dimiliki. Selain itu sebagian besar responden tidak bekerja yaitu sebanyak $75 \%$ ibu hamil untuk itu sebagai ibu rumah tangga informasi yang diterima pun kurang untuk didapat.

Bagi Dinas Kesehatan untuk melakukan peningkatan perencanaan dalam meningkatkan kesehatan ibu hamil melalui promosi kesehatan mengenai antenatal care disetiap Puskesmas dengan menggunakan leaflet, poster, spanduk maupun baliho yang dipasang di setiap Puskesmas maupun di posyandu-posyandu agar dapat meningkatkan pengetahuan ibu mengenai pentingnya antenatal care.

Upaya yang dilakukan yaitu sangat diperlukan peran petugas kesehatan puskesmas untuk memberikan informasi melalui konseling mengenai kunjungan antenatal care. Sehingga dengan pengetahuan yang dimiliki, ibu dapat mengetahui mengenai pentingnya kunjungan antenatal care sehingga ibu akan melakukan pemeriksaan kehamilan untuk mengupayakan kesehatan dirinya dan bayinya. Selain itu peran petugas kesehatan juga penting dalam melakukan penyuluhan secara rutin dan baik di puskesmas maupun di posyandu pada ibu hamil maupun pada masyarakat. Selain itu penyuluhan juga dapat diberikan pada pelaksanaan senam hamil.

Peran serta masyarakat juga dibutuhkan dalam pelaksanaan meningkatkan pelaksanaan antenatal care dengan meminta bantuan petugas kesehatan di Puskesmas untuk membentuk kelas ibu hamil di wilayahnya sehingga dengan adanya kelas ibu hamil akan meningkatkan pengetahuan ibu mengenai pentingnya antenatal care.

\section{Gambaran Sikap lbu Hamil Tentang Antenatal Care di Puskesmas Aur Duri Kota Jambi Tahun 2018}

Berdasarkan hasil penelitian yang diperoleh menggambarkan bahwa sebagian besar ibu hamil memiliki sikap positif yaitu 25 $(62,5 \%)$ ibu hamil dan yang memiliki sikap negatif sebanyak $15(37,5 \%)$ ibu hamil.

Sikap yang positif terhadap antenatal care dapat dipengaruhi oeh pengetahuan ibu hamil yang baik karena didapat bahwa sebagian besar responden memiliki pengetahuan yang baik sebanyak $67,5 \%$. Sehingga dengan pengetahuan yang baik tentang antenatal care akan membuat ibu menganggap penting tentang antenatal care. Sikap yang negatif dapat dipengaruhi oleh pengetahuan ibu yang masih kurang baik karena masih terdapat ibu hamil yang memiliki sikap yang negatif yaitu sebanyak $32,5 \%$. Sehingga dengan kurangnya pengetahuan ibu maka ibu menganggap tidak penting tentang antenatal care sehingga sikapnya menjadi negatif.

Berdasarkan hasil penelitian di atas masih terdapat responden yang memiliki sikap negatif terhadap antenatal care yaitu sebanyak 12 responden $(37,5 \%)$. Sikap responden yang kurang baik disebabkan karena pengetahuan yang masih kurang mengenai antenatal care. Terlihat bahwa pengetahuan seseorang mapun faktor dari lingkungan secara tidak langsung akan mempengaruhi sikap dan perilaku seseorang untuk melakukan antenatal care.

Upaya yang perlu dilakukan untuk meningkatkan sikap pada responden sangat diperlukan peran dari petugas kesehatan untuk selalu memberikan penyuluhan dan konseling bagi ibu hamil mengenai kunjungan antenatal care. Selain itu peran keluarga juga diperlukan untuk meningkatkan sikap ibu untuk melakukan kunjungan antenatal care sehingga dengan informasi yang didapat membuat sikap ibu menjadi lebih baik lagi. 


\section{SIMPULAN}

Berdasarkan hasil penelitian dapat disimpulkan sebagai berikut:

1. Sebagian besar ibu hamil memiliki pengetahuan baik yaitu $27(67,5 \%)$.

2. Sebagian besar ibu hamil memiliki sikap positif yaitu $25(62,5 \%)$.

3. Sebagian besar ibu hamil melakukan antenatal care dengan baik yaitu $36(90 \%)$ ibu hamil.

\section{DAFTAR PUSTAKA}

Ariani, A. 2012. Aplikasi Metodologi Penelitian Kebidanan dan Kesehatan Reproduksi. Yogyakarta: Nuha Medika.

Arikunto, S. 2012. Prosedur Penelitian. PT Rineka Cipta. Jakarta.

Chandra. F, dkk. 2015. Panduan Penulisan Skripsi dan Karya Tulis IImiah. STIKBA Jambi.

Dinkes Kota Jambi. 2016. Jumlah Sasaran WUS, Penderita Kanker Serviks di 20 Puskesmas Kota Jambi Tahun 2015. Kota Jambi.

Kumalasari, I. 2012. Kesehatan Reproduksi. Salemba Medika. Jakarta.

Maryanti, Dwi. 2009. Buku Ajar Kesehatan Reproduksi. Nuha Medika. Yogyakarta.

Notoadmodjo, S. 2010. Metodologi Penelitian Kesehatan. Rineka Cipta. Jakarta

Notoadmodjo, S. 2010. IImu Perilaku Kesehatan. PT Rineka Cipta. Jakarta.

Notoatmodjo, Soekidjo, 2012. Promosi Kesehatan dan IImu Perilaku. PT Rineka Cipta. Jakarta.

Nugroho, T. 2010. Kesehatan Wanita, Gender dan Permasalahannya. Yogyakarta : Nuha Medika

Nurwijaya, H. 2010. Cegah dan Deteksi Kanker Serviks. Flex Media Komputindo. Jakarta

Prawirohardjo, S. 2011. IImu Kandungan. PT Bina Pustaka Sarwono Prawirohardjo. Jakarta.

Prasetyawati, A,.E. 2012. Kesehatan lbu dan Anak (KIA). Nuha Medika. Yogyakarta.

Rasjidi. 2009. Deteksi Dini dan Pencegahan Kanker Pada Wanita. Sagungseto. Jakarta

Saryono, 2010. Metode Penelitian Kesehatan. Buku Kesehatan. Mitra Cendikia. Yogyakarta.

Utami. 2013. Hubungan Tingkat Pengetahuan Pasangan Usia Subur Dengan Perilaku Deteksi Dini Kanker Serviks. Jurnal. Universitas Muhamadiyah Surakarta

Wawan, A., dan Dewi M.2010. Teori dan Pengukuran Pengetahuan, Sikap dan Perilaku Manusia.Nuha Medika.Yogyakarta.

World Health Organization (WHO). 2006. Global Cancer Burden Rises TO 14.1 Million New Cases in 2012 : Marked increase in breasts cancers must be addressed. Switzerland. WHO.

Zuliyanti. 2013. Hubungan Pengetahuan Ibu Tentang Kanker Serviks Dengan Motivasi Pemeriksaan IVA di Puskesmas Rowokele tahun 2013. Jurnal 